\title{
EKSPERIMEN SAINS ANAK USIA 5-6 TAHUN DI TK AISYIYAH 5 RAWALO MELALUI PERMAINAN RAINBOW WALKING WATER (AIR PELANGI BERJALAN)
}

\author{
Tatik Ariyati ${ }^{1}$ \\ ${ }^{1}$ Universitas Muhammadiyah Purwokerto
}

\section{Article Info \\ Article history:}

Accepted April 22, 2021

Published April, 2021

Keywords:
experiment, $\quad$ science, $\quad$ rainbow

walking water

\begin{abstract}
This research is motivated by the creativity and innovation of teachers in making APE which is indispensable in developing children's science skills in schools resulting in less varied learning methods so that children are unable to construct their own knowledge of science and other knowledge. The purpose of this research is to find out how the experimental experiment through the rainbow water game runs in developing the scientific abilities of children aged 5-6 years. This research uses descriptive research with a qualitative approach. This research was conducted at TK Aisyiyah 5 Rawalo. The results of this study develop the development of children's scientific abilities and can also develop six aspects of child development, namely cognitive, language, emotional, moral and religious development, physicalmotor and art.
\end{abstract}

Copyright $@ 2021$ FKIP UMP All right reserved.

\section{Corresponding Author:}

Tatik Ariyati,

Program Studi Pendidikan Guru Sekolah Dasar,

Universitas Muhammadiyah Purwokerto,

Jl. KH. Ahmad Dahlan, Po. Box 202 Purwokerto, Banyumas, Indonesia.

Email: tatikariyati26@gmail.com

\section{How to Cite:}

Ariyati, T. (2021). Eksperimen Sains Anak Usia 5-6 Tahun Di Tk Aisyiyah 5 Rawalo Melalui Permainan Rainbow Walking Water (Air Pelangi Berjalan). Pendidikan-Jurnal Ilmiah Kependidikan (JIK), 15(1), 9297.

\section{PENDAHULUAN}

Anak usia dini merupakan seorang individu yang sedang melakukan sebuah proses pertumbuhan dan perkembangan yang sangat pesat untuk melanjutkan ke kehidupan selanjutnya. Pada masa usia dini disebut dengan masa golden age karena pada masa itu anak memiliki perkembangan agama dan moral, perkembangan fisik dan motorik, perkembangan emosional dan kognitif yang tumbuh dan berkembang dengan cepat. Maka untuk meningkatkan seluruh aspek perkembangan yang ada pada diri anak, diperlukan adanya penyelenggaraan pendidikan untuk anak usia dini dengan memberikan upaya untuk menstimulasi, membimbing, mengasuh, dan memberikan kegiatan pembelajaran. 
Dikutip dalam jurnal Yani Mustika (Mustika, et al., 2018) Djamarah (2010) menyatakan bahwa "Pendidikan merupakan usaha manusia yang artinya manusialah yang mengembangkan makna pendidikan yang berfungsi untuk kehidupan manusia yang lebih baik". Sedangkan menurut Undang-undang Mendiknas Nomor 20 Tahun 2003, tentang sistem pendidikan nasional pasal 1 ayat 1 , pendidikan adalah usaha sadar dan terencana untuk mewujudkan suasana belajar dan proses pembelajaran agar peserta didik secara aktif mengembangkan potensi diri, kepribadian, kecerdasan, akhlak mulia, serta keterampilan yang diperlukan dirinya, masyarakat, bangsa, dan negara. Untuk mencapai tujuan pendidikan tersebut maka dilakukan dengan proses belajar yang dapat mengubah tingkah laku individu yang bersangkutan serta mengembangkan kreativitas, sikap, dan perilaku. Proses belajar tersebut akan lebih optimal jika dilakukan sejak anak berusia dini.

Pendidikan Anak Usia Dini (PAUD) adalah pendidikan yang diselenggarakan dengan tujuan untuk memfasilitasi pertumbuhan dan perkembangan anak secara menyeluruh atau menekankan pada pengembangan seluruh aspek kepribadian anak. Oleh karena itu, PAUD memberikan kesempatan bagi anak untuk mengembangkan kepribadian dan potensi secara maksimal. Atas dasar ini, lembaga PAUD perlu menyediakan berbagai kegiatan ketika belajar dalam kelas yang dapat mengembangkan berbagai aspek perkembangan seperti kognitif, bahasa, sosial, emosi, fisik, dan motorik (Suyadi, 2014:2223).

Metode-metode pembelajaran yang sesuai dengan karakteristik anak usia dini: bermain, karyawisata, bercakap-cakap, bercerita, demonstrasi atau eksperimen, proyek, pemberian tugas (Moeslichatoen, 2004: 24).

Salah satu cara untuk menstimulasi perkembangan anak usia dini yaitu dengan pemberian pengajaran dan pendidikan dengan kegiatan yang kreatif dan inovatif serta menciptakan suasana belajar yang menarik dan menyenangkan bagi anak usia dini yaitu dengan menggunakan kegiatan eksperimen sains. Kegiatan eksperimen sains menjadi salah satu kegiatan anak usia dini untuk menstimulasi perkembangan kreativitas anak serta anak belajar untuk berani mencoba hal-hal yang berhubungan dengan sains. Menurut Yeni dalam Suryameng dan Marselina (2019) metode eksperimen merupakan cara penyajian bahan pelajaran dimana siswa melakukan percobaan dengan mengalami untuk membuktikan sendiri sesuatu pertanyaan atau hipotesis yang dipelajari. Eksperimen atau percobaan dapat dikatakan sebagai suatu proses yang harus dikuasi anak sebagi suatu cara untuk memahami konsep tentang sesuatu hal ataupun penguasaan anak tentang konsep dasar eksperimen, melainkan bagaimana mereka dapat mengetahui cara atau proses terjadinya sesuatu dan mengapa sesuatu dapat terjadi serta bagaimana mereka dapat menemukan solusi terhadap permasalahan yang ada dan pada akhirnya mereka dapat membuat sesuatu yang bermanfaat dari kegiatan tersebut.

Sains adalah pembelajaran yang mempelajari pengetahuan alam yang dilakukan dengan pengamatan. Sains merupakan cara kita berpikir dan melihat dunia sekitar kita yang menyajikan fakta-fakta atau kenyataan yang terkait dengan fenomena alam (Desmita, 2007: 29). Sains sebagai bidang ilmu alamiah, dengan ruang lingkup zat dan energi, baik yang terdapat pada benda hidup maupun benda mati, yang lebih membahas tentang alam (natural science) seperti fisika, kimia dan biologi, Nugraha (2008: 3). Sedangkan menurut

Pembelajaran sains pada anak usia dini merupakan konsep sains sederhana berupa pengenalan warna, pencampuran warna, tumbuhan, binatang, gejala alam dan lain sebagainya. Anak-anak sebaiknya diajarkan bagaimana merasakan, mengalami, dan mencoba berbagai fenomena yang terjadi di alam semesta. Seperti kegiatan yang berhubungan dengan eksperimen ini yaitu eksperimen pengenalan dan pencampuran warna, dan sifat air. Eksperimen ini akan mengembangkan kreativitas anak, anak belajar 
untuk berani mencoba sesuatu hal yang baru sehingga anak mendapatkan pengalaman yang berharga untuk bekal saat anak dewasa. Anak akan mengamati, menganalisis dan mengevaluasi informasi yang ada, dengan melakukan percobaan-percobaan sains dan keterampilan proses anak-anak dapat ditingkatkan kemampuan sainsnya. Trianto (2012:138) menemukakan bahwa tujuan sains berdasarkan kurikulum berbasis kompetensi adalah sebagai berikut: 1) menanamkan keyakinan terhadap Tuhan YME; 2) mengembangkan keterampilan sikap dan nilai-nilai ilmiah; 3) mempersiapkan siswa menjadi warga negara yang melek sains dan teknologi; 4) menguasai konsep sains untuk bekal hidup di masyarakat dan melanjutkan pendidikan kejenjang lebih tinggi.

Bermain merupakan kegiatan belajar anak. Eksperimen sains pada anak usia dini menggunakan konsep bermain, sehingga anak lebih mudah memahami makna dari kegiatan tersebut dan anak dapat membuat anak merasa senang. Menurut Gordon dkk. (Sari, 2012) bermain merupakan pekerjaan bagi anak di masanya dan cermin pertumbuhan bagi anak. Bermain merupakan wadah bagi anak untuk berlatih, mengeksploitasi serta merekayasa yang diulang-ulang dengan menggunakan alat atau tidak guna memperoleh informasi, kesenangan dan mengembangkan daya imajinasinya. Melalui bermain sains diharapkan anak dapat mengembangkan kognitifnya, meningkatkan pemahaman, penalaran dan memahami serta mencintai lingkungan, membentuk daya imajinasi dan dunia sesungguhnya. Dengan bermain anak juga dapat mengembangkan kemampuan bersosialisasi, mengetahui berbagai konsep dan melatih kesabaran.

Eksperimen sains melalui permainan rainbow walking water atau air berjalan merupakan permainan yang dibuat yang bertujuan untuk mengembangkan kemampuan sains pada anak usia 5-6 tahun. Bermain dengan menggunakan air merupakan kesenangan bagi anak. Guru bisa mengarahkan permainan menggunakan air agar anak memiliki pengalaman dan pengetahuan tentang air. Air memiliki sifat menyesuaikan bentuk dengan wadahnya, serta selalu mengalir dari tempat yang lebih tinggi ke tempat yang lebih rendah dan dari tempat yang bertekanan tinggi ke tempat yang bertekanan rendah. Permainan ini merupakan suatu cara melatih anak memahami sifat-sifat air.

Permainan rainbow walking water dirancang berdasarkan prinsip-prinsip pembelajaran sains, yaitu: (1) Konkrit dan dapat dilihat langsung oleh anak sehingga anak dapat dilatih untuk membuat hubungan sebab akibat. (2) Bersifat pengalaman, pembelajaran yang menekankan proses pengenalan berbagai benda dan fenomena alam. (3) Seimbang antara kegiatan fisik dan mental. Anak dapat menggunakan kelima indranya untuk melakukan observasi terhadap berbagai benda, gejala benda, dan gejala peristiwa. (4) Sesuai tingkat perkembangan anak, baik usia maupun dengan kebutuhan individual anak. (5) Mengembangkan kecerdasan anak. (6) Sesuai gaya belajar anak karena tipe dan modalitas belajar setiap anak berbeda yang menyebabkan anak belajar dengan cara berbeda pula. (7) Kontekstual dan menggunakan banyak konteks. (8) Sebaiknya bersifat terpadu atau terintegrasi. (9) Menggunakan prinsip belajar, bermain dan bernyanyi. (10) Belajar dari benda konkrit.

Namun pada kenyataanya guru hanya memberikan metode pembelajaran sains dengan ceramah dan beberapa tugas. Sehingga anak tidak bisa mengkonstruksi pengetahuannya sendiri. Untuk itu melalui permainan rainbow walking water ini permasalahan yang sering muncul di sekolah dapat diatasi dan menjadi salah satu referensi untuk guru dalam mengembangkan alat permainan edukatif. TK Aisyiyah 5 Rawalo yang terletak di Kecamatan Rawalo, Kabupaten Banyumas, Provinsi Jawa Tengah, merupakan salah satu lembaga pendidikan anak usia dini yang memanfatkan alat permainan edukatif sebagai sumber belajar. Adapun rumusan masalah dalam penelitian ini yaitu bagaimana eksperimen sains melalui permainan rainbow walking water ini dalam mengembangkan kemampuan sains anak usia 5-6 tahun di TK Aisyiyah 5 Rawalo? Berdasarkan latar 
belakang tersebut, maka peneliti tertarik untuk melakukan penelitan mengenai eksperimen sains dengan rainbow walking water untuk kemampuan sains anak dengan judul "Eksperimen Sains Anak Usia 5-6 Tahun di TK Aisyiyah 5 Rawalo Melalui Permainan Rainbow Walking Water (Air Pelangi Berjalan)".

\section{METODOLOGI}

Penelitian ini dilakukan di TK Aisyiyah 5 Rawalo yang terletak di Kecamatan Rawalo, Kabupaten Banyumas, Provinsi Jawa Tengah. Adapun tujuan penelitian ini untuk mengetahui bagaimana eksperimen sains melalui permainan rainbow walking water (air pelangi berjalan) dalam mengembangkan kemampuan sains anak usia 5-6 tahun. Subjek penelitian ini adalah anak TK Aisyiyah 5 Rawalo berjumlah 16 anak.

Penelitian ini menggunakan jenis penelitian deskriptif dengan pendekatan kualitatif. Menurut Mogdan dan Tylor (Roza, 2012) prosedur penelitian yang menghasilkan data deskriptif berupa kata-kata tertulis atau lisan dari orang-orang dan perilaku yang dapat diamati. Sebagaimana menurut Moleong data-data yang terkumpul berupa kata-kata dan gambar.

Penelitian ini menggunakan bentuk Penelitian Lapangan (field research) yaitu melihat dan menggambarkan apa adanya kajian tentang kemampuan sains anak melalui eksperimen rainbow walking water. Responden yang terlibat dalam penelitian ini yaitu siswa, guru, dan kepala sekolah. Sedangkan instrumen yang digunakan dalam penelitian ini menggunakan observasi, wawancara dan dokumentasi. Teknik analisis data dalam penelitian ini yaitu reduksi data dengan merangkum, memilih hal-hal pokok, memilih tema dan polanya serta memfokuskan pada hal-hal yang penting. Penyajian data disajikan dalam bentuk uraian singkat sehingga memudahkan dalam memahami apa yang terjadi dan merencanakan kerja selanjutnya berdasar apa yang telah dipahami, kemudian ditarik kesimpulan. Data yang telah disimpulkan agar diverifikasi selama penelitian berlangsung. Selanjutnya pengabsahan data yang digunakan yaitu triangulasi. Menurut Moleong (2007) triangulasi merupakan suatu teknik pemeriksaan data dengan memanfaatkan suatu hal lain sebagai data pembanding dengan tujuan untuk membuktikan apa yang diamati sesuai dengan keadaan yang sesungguhnya. Ada empat macam triangulasi sebagai teknik pemeriksaan yaitu sumber, metode, penyidik dan teori.

\section{HASIL DAN PEMBAHASAN}

Permainan rainbow walking water merupakan permainan yang bisa digunakan anak usia 5-6 tahun untuk menstimulasi kemampuan sains. Adapun aspek yang juga dapat distimulasi melalui permainan ini yaitu: (1) Perkembangan Kognitif; anak memiliki kesempatan untuk mengetahui sifat-sifat air, yang selalu mengalir ke tempat yang lebih rendah, mengukur dan mengenal konsep banyak dan sedikit, serta mengenal pencampuran warna. (2) Perkembangan Motorik; menuangkan air ke dalam gelas, meneteskan pewarna makanan ke dalam air, mengaduk air di dalam gelas, melipat tissu. Kegiatan tersebut dapat melatih motorik halus anak. (3) Perkembangan Sosial-Emosional; anak dapat belajar bersosialisasi dan berinteraksi dengan teman atau guru. Interaksi tersebut akan mengajarkan anak cara merespon, memberi dan menerima tanggapan, menolak atau menerima ide/perilaku anak lain. Sedikit demi sedikit hal tersebut akan mengurangi rasa egois anak serta mampu mengembangkan kemampuan sosialisasinya. Sedangkan secara emosional akan melatih kesabaran, anak merasa gembira dan takjub ketika menggunakan permainan ini. (4) Perkembangan Bahasa; melalui tanya jawab anak mampu berkomunikasi dengan teman dan guru yang berarti melatih menggunakan bahasa untuk 
berkomunikasi dan menyatakan ide-ide atau pikirannya. (5) Moral dan Agama; mengenalkan anak bahwa air merupakan ciptaan Allah. Kegiatan ini melatih anak untuk bersyukur atas ciptaan Allah. (6) Seni; anak akan mengenal jenis warna pada alat permainan tersebut.

Untuk membuat permainan ini, memerlukan alat dan bahan yaitu: 7 buah gelas plastik, air, pewarna makanan (biru, merah, kuning), sendok, spidol dan 6 lembar tissue wajah. Sedangkan langkah-langkah permainan: (1) berilah nomer pada setiap gelas dari 1 sampai. (2) Anak menuangkan air ke dalam gelas nomer 1, 3, 5, dan 7. (3) Teteskan pewarna makanan warna biru pada gelas nomer 1, warna merah pada gelas nomer 3, warna kuning pada gelas nomer 5, dan warna biru pada gelas nomer 7. (4) Aduklah menggunakan sendok dan air dan pewarna makanan menjadi tercampur. (5) Anak melipat tissu sebanyak 6 lembar yang masing-masing dilipat menjadi 3 lipatan sehingga membentuk persegi panjang. (6) Masukkan ujung tisu masing-masing ke dua gelas yang bersebelahan. (7) Anak mengamati perpindahan air dari air yang berisi air ke gelas yang kosong, sehingga air seolah-olah berjalan. (8) Kemudian terjadilah pencampuran warna, sehingga menghasilkan warna baru.

Tujuan permainan yaitu mengenalkan kepada anak konsep sains berupa sifat air dan pencampuran warna. Dalam permainan ini terdapat konsep bahwa air selalu mengalir dari tempat yang lebih tinggi ke tempat yang lebih rendah, dan air selalu mengikuti bentuk bejana.

\section{SIMPULAN DAN SARAN}

Permainan rainbow walking water merupakan suatu alat permainan edukatif yang dirancang untuk mengembangkan kemampuan sains anak usia 5-6 tahun. Selain itu permainan ini juga dapat mengembangkan aspek kognitif, fisik motorik, bahasa, moral dan agama, sosial-emosional serta seni.

Permainan rainbow walking water dirancang berdasarkan prinsip-prinsip pembelajaran sains, yaitu: (1) Konkrit dan dapat dilihat langsung oleh anak sehingga anak dapat dilatih untuk membuat hubungan sebab akibat. (2) Bersifat pengalaman, pembelajaran yang menekankan proses pengenalan berbagai benda dan fenomena alam. (3) Seimbang antara kegiatan fisik dan mental. Anak dapat menggunakan kelima indranya untuk melakukan observasi terhadap berbagai benda, gejala benda, dan gejala peristiwa. (4) Sesuai tingkat perkembangan anak, baik usia maupun dengan kebutuhan individual anak. (5) Mengembangkan kecerdasan anak. (6) Sesuai gaya belajar anak karena tipe dan modalitas belajar setiap anak berbeda yang menyebabkan anak belajar dengan cara berbeda pula. (7) Kontekstual dan menggunakan banyak konteks. (8) Sebaiknya bersifat terpadu atau terintegrasi. (9) Menggunakan prinsip belajar, bermain dan bernyanyi. (10) Belajar dari benda konkrit.

Kreativitas dan inovasi guru dalam membuat APE sangat diperlukan dalam pengembangan kemampuan sains anak di sekolah mengakibatkan kurang bervariasinya metode pembelajaran sehingga anak tidak mampu mengkonstruksi pengetahuannya sendiri mengenai sains dan pengetahuan lainnya. Untuk itu diharapkan permainan dan penelitian ini bisa menjadi salah satu referensi guru dalam mengembangkan metode pembelajaran disekolah terutama pengembangan sains anak. 


\section{REFERENSI}

Desmita. 2007. Psikologi Perkembangan. Bandung: PT Remaja Rosdakarya Moeslichatoen. 2004. Metode Pengajaran di Taman Kanak-Kanak. Jakarta: Rineka Cipta

Moloeng, Lexy J. 2007. Metode Penelitian Kualitatif. Bandung. PT. Remaja Rosdakarya Mustika dan Nurwidaningsih. 2018. Pengaruh Percobaan Sains Anak Usia Dini terhadap Perkembangan Kognitif Anak di TK Kartika Siwi Pusdikpal Kota Cimahi. Jurnal Obsesi: Jurnal Pendidikan Anak Usia Dini Vol 2 No 1 (2018) Page 94 - 101

Nugraha. 2008. Pengembangan Pembelajaran Sains pada Anak Usia Dini. Jakarta: Departemen Pendidikan Nasional

Roza, M. M. (2012). Pelaksanaan Pembelajaran Sains Anak Taman Kanak-Kanak Aisyiyah Bustanul athfal 29 Padang. Jurnal Pesona PAUD, 1(17)

Sari, Y. (2012). Peningkatan Kemampuan Sains Anak Usia Dini Melalui Metode Demonstrasi di Taman Kanak-kanak Tri Bina Payakumbuh. Jurnal Pesona PAUD, 1(1).

Suryameng dan Marselina. 2019. Metode Eksperimen dalam Pembelajaran Sains untuk Meningkatkan Kemampuan Kognitif Anak Usia Dini di TK Santa Yohana Antida 2 Sintang. Jurnal Pendidikan Anak Usia Dini Vol 1 Halaman 46-58

Suyadi. 2014. Teori Pembelajaran Anak Usia Dini. Bandung: PT Remaja Rosdakarya

Trianto. 2012. Model Pembelajaran Terpadu Konsep, strategi dan Implementasinya dalam KTSP. Jakarta. Bumi Aksara

\section{http://jurnalnasional.ump.ac.id/index.php/khazanah}

